\title{
Regulation of ovarian function by the TGF- $\beta$ superfamily and follistatin
}

\author{
Shyr-Yeu Lin ${ }^{1,2}$, John R. Morrison ${ }^{1}$, David J. Phillips ${ }^{1}$ and David M. de Kretser ${ }^{1 *}$ \\ ${ }^{1}$ Centre for Molecular Reproduction and Endocrinology, Monash Institute of Reproduction and \\ Development, Monash University, Melbourne, Victoria 3168, Australia; and ${ }^{2}$ Department of Obstetrics \\ and Gynecology, Mackay Memorial Hospital, Taipei, Taiwan
}

\begin{abstract}
The role of follistatin as an activin-binding protein has dominated the study of this molecule for the last 10 years. However, there is emerging evidence that follistatin has a role in modulating the biology of other members of the transforming growth factor $\beta$ (TGF- $\beta$ ) superfamily. This review summarizes the current concepts encompassing follistatin biochemistry as well as molecules with which it is functionally associated. Moreover, the importance of the two follistatin isoforms (follistatin-288 and follistatin-315) is discussed with particular emphasis on the regulation of the ovary. In addition to activin, this review discusses the functions of other members of the TGF- $\beta$ superfamily, for example growth differentiation factor 9 (GDF-9), bone morphogenetic protein 15 (BMP-15), BMP-6, BMP-4 and BMP-7, in the ovary, and the potential interactions between follistatin and these growth factors. The complex network of TGF- $\beta$ superfamily growth factor members involved in the modulation of ovarian function and the interactions of follistatin with these proteins is highlighted.
\end{abstract}

The proteins inhibin, activin and follistatin were isolated from gonads by their ability to modulate pituitary $\mathrm{FSH}$ secretion. Activin stimulates FSH whereas inhibin and follistatin are inhibitory (Ling et al., 1985; Robertson et al., 1985; Ling et al., 1986; Vale et al., 1986; Robertson et al., 1987; Ueno et al., 1987). The inhibins and activins, members of the transforming growth factor $\beta$ (TGF- $\beta$ ) superfamily, are known to play pivotal roles in developmental and reproductive processes. Follistatin, a glycosylated single-chain protein with no structural similarity to but functionally linked to members of the TGF- $\beta$ superfamily, was also isolated by its suppression of FSH secretion by pituitary cells (Esch et al., 1987; Robertson et al., 1987). Subsequently, follistatin was shown to be an activin-binding protein (Nakamura et al., 1990), which acts by binding and neutralizing the actions of the activins. Physiological studies have demonstrated that the inhibins function principally as reproductive hormones (DePaolo 1997; Mather et al., 1997), whereas the activins have predominantly paracrine or autocrine functions (DePaolo, 1997; Mather et al., 1997). In addition to inhibiting the actions of the activins, follistatin binds and regulates the function of other members of the TGF- $\beta$ superfamily, thereby expanding its range of actions. This review will focus on the biochemical

*Correspondence

Email: david.de.kretser@med.monash.edu.au characteristics of follistatin in relation to its influence on ovarian function.

\section{TGF- $\beta$ superfamily}

The TGF- $\beta$ superfamily of growth factors includes more than 30 structurally related mammalian proteins that have diverse functions during embryonic development and adult tissue homeostasis. They can be grouped into three families: the TGF- $\beta$ family, the activin family, and the bone morphogenetic protein (BMP) family, although some TGF- $\beta$ superfamily members may fall outside these three groupings.

Members of the TGF- $\beta$ superfamily are synthesized as large precursor proteins that are composed of an amino-terminal signal sequence, a pro-domain and a mature domain (carboxyl-terminal domain) (Fig. 1a). The amino-terminal signal may direct the precursor to a secretory pathway. The variable pro-domain may facilitate folding, dimerization and regulation of TGF- $\beta$ superfamily members (Kingsley, 1994). The signalling parts of the molecules are the hetero- or homodimers of the highly conserved carboxyl-terminal domain, most of which contain seven conserved cysteine residues. Six of these cysteines, forming three disulphide bonds within each monomer subunit, interact to build a structure termed a cystine knot (Fig. 1b). This knot consists of an eight-member ring constructed from two disulphide bonds, with a third disulphide bond 


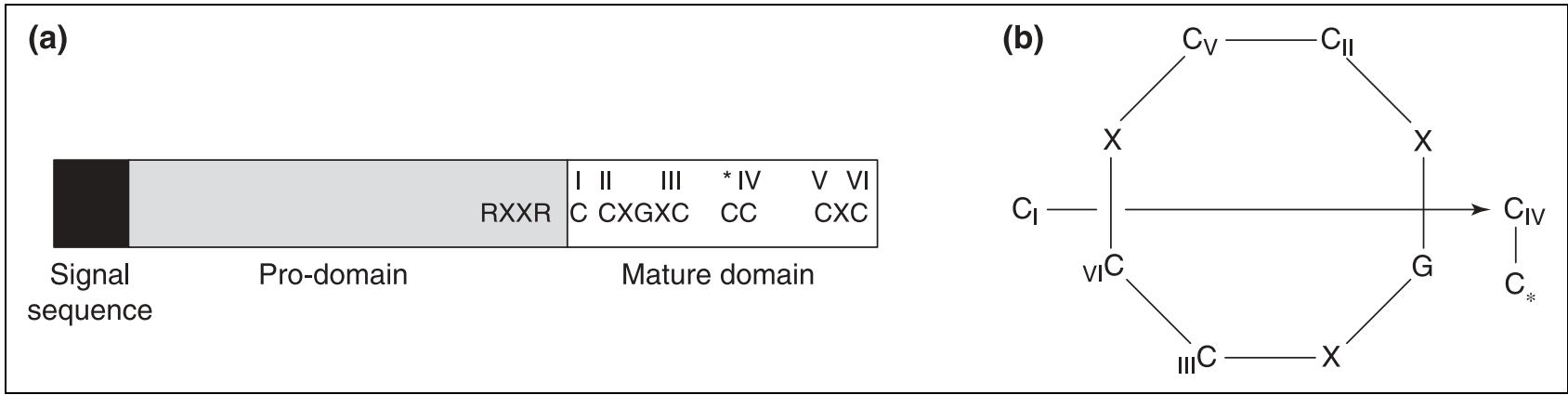

Fig. 1. Structure of transforming growth factor $\beta$ (TGF- $\beta$ ) superfamily members. (a) A precursor protein of monomers of TGF- $\beta$ superfamily members consists of a signal sequence, pro-domain and a mature domain (carboxyl-terminal domain). Cleavage at a dibasic site (RXXR motifs) releases a mature domain that contains seven highly conserved cysteine residues, forming three intramonomeric disulphide bonds $\left(\mathrm{C}_{\mathrm{I}}-\mathrm{C}_{\mathrm{IV}}, \mathrm{C}_{\mathrm{II}}-\mathrm{C}_{V}\right.$ and $\left.\mathrm{C}_{\mathrm{III}}-\mathrm{C}_{\mathrm{VI}}\right)$. (b) The cystine knot motif arises from the three intra-monomeric disulphide bonds by two $\left(\mathrm{C}_{\mathrm{II}}-\mathrm{C}_{\mathrm{V}}\right.$ and $\left.\mathrm{C}_{\mathrm{III}}-\mathrm{C}_{\mathrm{VI}}\right)$ of them building an eight-membered ring structure, through which the third $\left(\mathrm{C}_{\mathrm{I}}-\mathrm{C}_{\mathrm{IV}}\right)$ passes. The remaining cysteine (labelled with *) forms an inter-monomeric disulphide bond with that of the other monomer into a dimmer. (Based on Böttner et al. 2000.)

threaded through the central area of the ring (Daopin et al., 1992; Schlunegger and Grutter, 1992; Böttner et al., 2000). Moreover, this knot locks the base of several $\beta$-sheet strands together apparently contributing to the stabilization of TGF- $\beta$ superfamily members in various conformations. The remaining cysteine residue in each monomer forms an additional disulphide bond that links two monomers into a dimer (Fig. 1b). This cysteine is missing in some members, for example growth differentiation factor 3 (GDF-3) and 9 (GDF-9). However, there are many hydrophobic contacts between the two monomer subunits that may promote dimerization even in the absence of a disulphide bond (Kingsley, 1994).

The inhibins are dimers of a unique $\alpha$-subunit dimerized to either a $\beta A$ or $\beta B$ subunit, giving inhibin $A$ $(\alpha-\beta A)$ or inhibin $B(\alpha-\beta B)$. Homo-dimerization or heterodimerization of either $\beta A$ or $\beta B$ subunits generates three activins, named activin $A(\beta A-\beta A)$, activin $B(\beta B-\beta B)$ and activin $A B(\beta A-\beta B)$. Three additional $\beta$ subunits (mammalian $\beta C$ and $\beta \mathrm{E}$, and Xenopus $\beta \mathrm{D}$ ) have also been cloned (Oda et al., 1995; Fang et al., 1996; Schmitt et al., 1996). Although their functions are yet to be determined, a study by Vejda et al. (2002) demonstrated that the liver is the major organ for production of $\beta C$ and $\beta E$ subunits and potential dimerization occurs between $\beta A$ and $\beta C$ subunits, $\beta A$ and $\beta E$ subunits, and $\beta C$ and $\beta E$ subunits. Moreover, co-transfection studies indicate that the $\beta C$ subunit is unable to form a dimer with the inhibin $\alpha$ subunit (Mellor et al., 2000).

In addition to the inhibins and activins, to date myostatin (also called GDF-8), BMP-4, BMP-7 and BMP15 (also called GDF-9B) have all been identified as potential binding partners of follistatin. It is very likely that other members of the TGF- $\beta$ superfamily that interact with follistatin will be reported in the future. The functions of the members that are associated with follistatin are discussed in the following sections.

\section{Signalling pathways of the TGF- $\beta$ superfamily}

Members of the TGF- $\beta$ superfamily use a common mechanism to signal to the nucleus. They bind to cell membrane receptors, which have an intracytoplasmic serine/threonine kinase domain, leading to the assembly of a receptor complex that phosphorylates proteins of the SMAD family. The SMADs then move into the nucleus, bind DNA and recruit the required transcriptional coactivators or co-repressors to control gene expression (Massagué, 1998; Massagué and Wotton, 2000) (Fig. 2). SMAD is a fusion of the names of two genes, the Drosophila gene Mad (mothers against $\underline{d p p}$ ) and the C. elegans gene sma (small body size). The specific pairs of receptors to which the ligands of the TGF- $\beta$ superfamily bind fall into two groups designated type I and type II receptors. Generally, each ligand has its own specific receptors; however, some receptors may be shared by different TGF- $\beta$ ligands. When the ligand binds to the receptor, it brings together two type I receptors and two type II receptors to form an activated receptor complex. In this complex, the type I receptor becomes phosphorylated by the type II receptor and in turn phosphorylates the SMAD proteins that transmit the signal (Massagué, 1998; Massagué and Wotton, 2000).

SMADs are classified into three groups based on their roles in the signalling pathways: the receptorregulated SMADs (R-SMADs), the common mediator SMAD (Co-SMAD), and the inhibitory SMADs (I-SMADs). In vertebrates, the type I receptors for activin, TGF- $\beta$ and nodal, signal through SMAD2 and SMAD3, whereas those for the BMPs, GDFs and anti-Müllerian hormoneMüllerian inhibiting substance (AMH-MIS) do so through SMAD1, SMAD5 and SMAD8. These SMADs are collectively called R-SMADs. The co-SMAD, SMAD4, is required to form a complex with the R-SMAD before moving into the nucleus. However, increased expression 


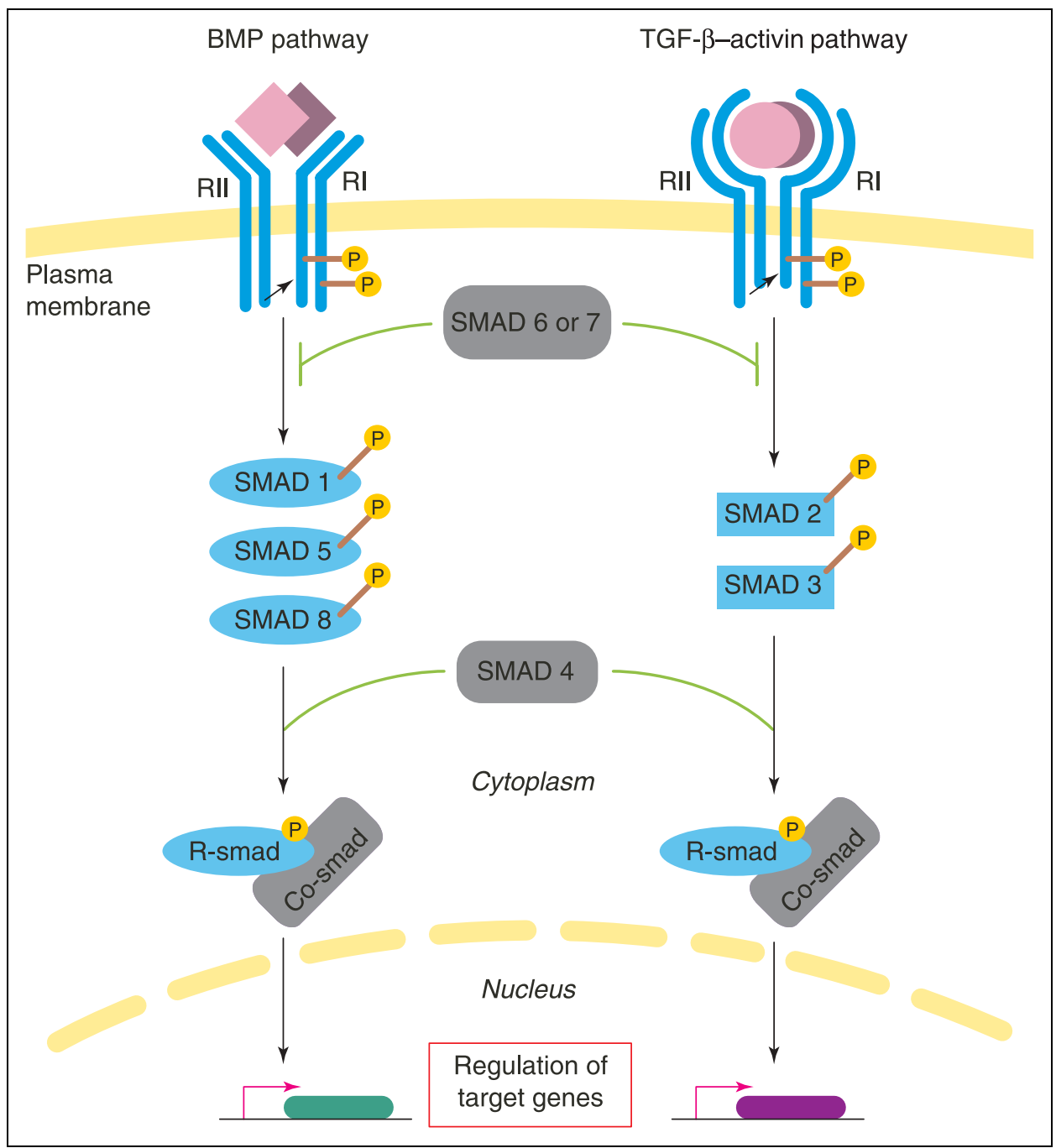

Fig. 2. The basic transforming growth factor $\beta$ (TGF- $\beta$ ) superfamily members SMAD pathway. After forming a ligand-receptor complex, the receptor I (RI), phosphorylated by the receptor II (RII), in turn phosphorylates R-SMAD (SMAD 2, 3 for TGF- $\beta$ /activin; SMAD 1, 5, 8 for bone morphogenetic proteins (BMPs)). The further assembly of R-SMAD and Co-SMAD (SMAD 4) makes the resulting SMAD complex free to move into the nucleus and regulate the target genes of TGF- $\beta$ superfamily members with some transcriptional co-activators or co-repressors.

of the I-SMADs, SMAD6 or SMAD7, inhibits TGF- $\beta$, activin and BMP signalling (Fig. 2). In addition, the signalling network of the TGF- $\beta$ superfamily has become more complex, as recent studies revealed that the SMAD signalling system is also modulated by crosstalk with other kinase signalling cascades (Derynck et al., 1998; Massagué and Wotton, 2000; Zimmerman and Padgett, 2000).

\section{Structural characterization of follistatins}

\section{The follistatin gene}

Follistatin protein is highly conserved among species with $97 \%$ amino acid homology between humans and mice (http://www.ncbi.nlm.nih.gov/cgi-bin/UniGene/).
The human follistatin gene localizes to chromosome 5q11.2 (http://www.ncbi.nlm.nih.gov/LocusLink/) and consists of six exons (Fig. 3). The first exon encodes the putative signal sequence, followed by four exons which encode four domains with the last three domains being very similar to each other. The last exon encodes for the 27 extra amino acids at the carboxyl terminal of the 344residue precursor (Shimasaki et al., 1988b).

Follistatin expression is tightly regulated during development (Feijen et al., 1994; Patel et al., 1999). To understand further the regulation of follistatin expression, several research groups studied the follistatin gene promoter. Characterization of the rat follistatin gene promoter identified three transcription start sites located at about $30 \mathrm{bp}$ downstream of three distinct TATA-like 


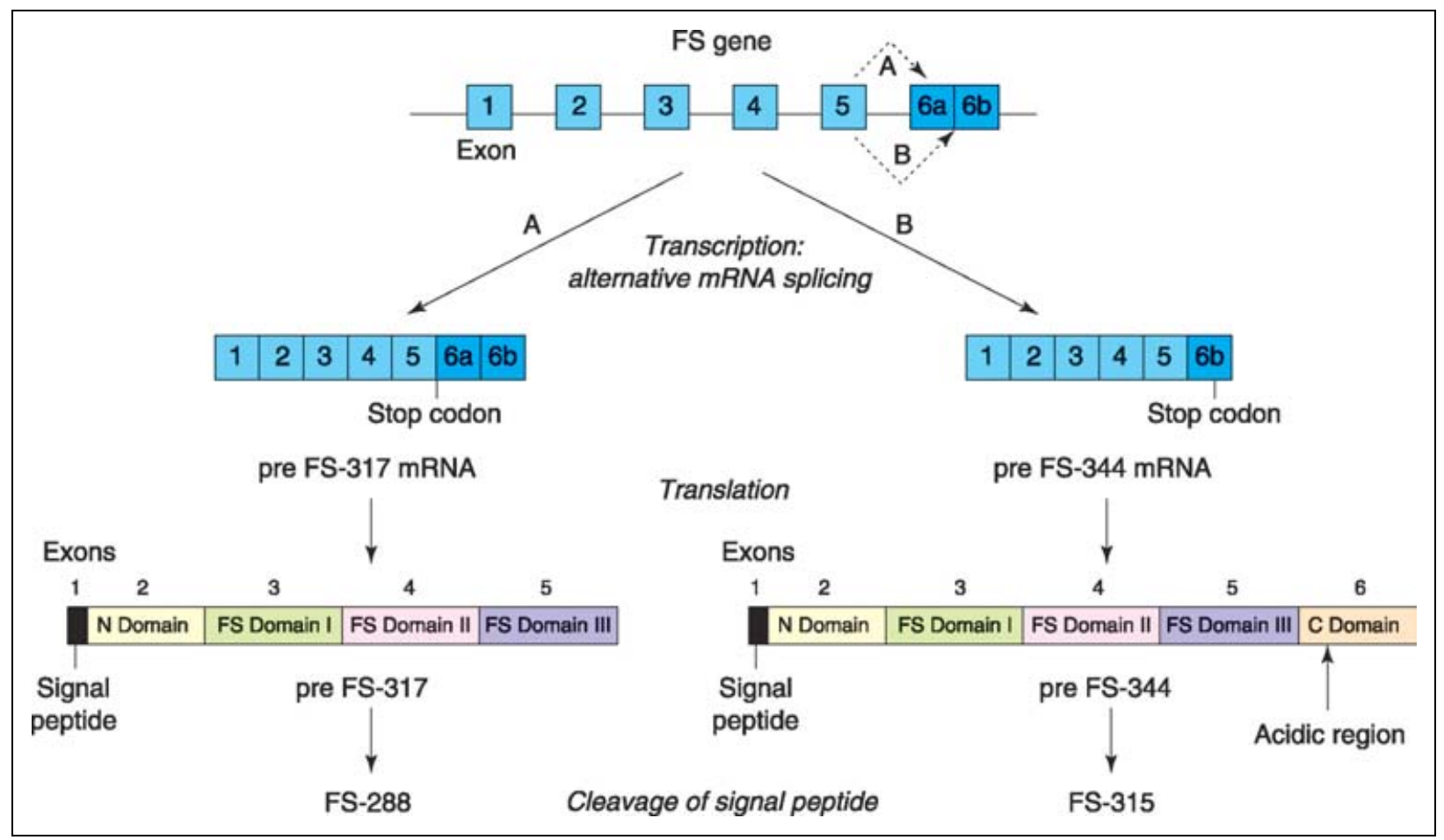

Fig. 3. Schematic representation of follistatin (FS) gene, alternative mRNA splicing and protein processing. Human follistatin gene 6 has six exons transcribed into the precursor follistatin-317 mRNA (pre FS-317 mRNA) and the precursor follistatin-344 mRNA (pre FS-344 mRNA) via alternative mRNA splicing. Both mRNA are then translated into pre FS-317 (a precursor of 317 amino acids of follistatin) and pre FS-344 (a precursor of 344 amino acids of follistatin), which subsequently become follistatin-288 (FS-288) and follistatin-315 (FS-315) by cleavage of signal peptide. FS-288 and FS-315 both have an N domain and FS domains I, II and III with an additional C domain in FS-315.

sequences. The promoter region revealed several DNA motifs for transcription factors, including Sp1, Ap-2, Ap-1, and a c-AMP-response element (CRE)-like sequence. de Groot et al. (2000) demonstrated that the murine follistatin promoter region has at least three distinct transcription initiation sites, which are each preceded by a TATA box with several consensus binding sites for transcription factors including Ap- 1 , Brachyury-T, CREbinding protein (CREB), Sp1, Ap-2 and Tcf (de Groot et al., 2000).

\section{Follistatin isoforms from alternative pre-mRNA splicing}

Molecular analysis of the various isoforms showed that follistatin is encoded by a single gene and the variety of molecular masses (31-39 kDa) arise from alternative splicing, glycosylation and proteolytic cleavage (Robertson et al., 1987; Ueno et al., 1987; Shimasaki et al., 1988b). Alternative splicing occurs at the 3 '-terminal of the gene between exon 5 and exon 6 (Fig. 3). The splicing out of intron 5, generating a stop codon following immediately the last amino acid of exon 5, leads to the termination of the coding sequence for a precursor of 317 amino acids (pre-follistatin 317), the $\mathrm{COOH}$-terminal truncated form. On the other hand, exon 6 a is spliced out together with intron 5 to generate a precursor of 344 amino acids (pre-follistatin 344) (Shimasaki et al., 1988a,b). Cleavage of the signal peptide ( 29 amino acids) generates the mature follistatin isoforms of 288 and 315 amino acids (follistatin-288 and follistatin-315). In addition, the majority of follistatin isolated from pig ovary is follistatin303 , which appears to be derived from follistatin-315 by proteolytic cleavage of the 12 C-terminal amino acids (Sugino et al., 1993).

\section{Function of follistatin as a binding protein}

The actions of follistatin are principally explicable by its ability to bind and neutralize various members of the TGF- $\beta$ superfamily. The activin-follistatin binding complex is generally considered to be composed of one activin and two follistatin molecules, whereas inhibin, containing one $\beta$-subunit, has only one binding site for follistatin, implying that follistatin binds to activin and inhibin through the common $\beta$ subunits (Shimonaka et al., 1991; de Winter et al., 1996). However, it is unclear whether follistatin can prevent inhibin binding to the activin receptor. The published estimates for the affinity 
$\left(K_{\mathrm{d}}\right.$ value) of follistatin for activin ranges from 50 to $900 \mathrm{pmol} \mathrm{I}^{-1}$, similar to that of activin for its receptors (from 100 to $400 \mathrm{pmol} \mathrm{I}^{-1}$; Phillips and de Kretser, 1998), and explains why follistatin functions as a potent modulator of the actions of activin.

In addition, follistatin antagonizes the actions of BMP4 in Xenopus embryos and mouse teratocarcinoma cells, and interacts directly with BMP-4 in vitro (Fainsod et al., 1997). Follistatin also inhibits the effects of OP-1 (also known as BMP-7), if added at a 10-fold excess (Yamashita et al., 1995). During the development of chick limbs, follistatin promotes the ability of BMP-7 to induce muscle growth but inhibits the ability of BMP-7 to induce apoptosis and muscle loss by flexible and reversible binding to BMP-7 (Amthor et al., 2002). lemura et al. (1998) demonstrated that in the early Xenopus embryo follistatin can inhibit the effects of BMP-2, -4 and -7 by direct binding to a complex of BMP and its receptor. Follistatin can also inhibit myostatin, another TGF- $\beta$ family member that acts as a negative regulator of skeletal muscle mass, from binding to receptors (Lee and McPherron, 2001). Recent data indicate that follistatin binds and suppresses the actions of BMP-15 (Otsuka et al., 2001a). Taken together, growing evidence indicates that follistatin not only functions as an activinbinding protein, but also interacts with other TGF- $\beta$ family members, presumably through a similar binding mechanism.

Importantly, the C-terminal amino acid sequence of follistatin appears to be critical for follistatin binding to heparan sulphate proteoglycans, as the C-terminal truncated form, follistatin-288, shows much higher affinity for the rat granulosa cell surface $\left(\mathrm{a} K_{\mathrm{d}}\right.$ value of $2 \mathrm{nmol} \mathrm{I}^{-1}$ ) than follistatin-303, whereas follistatin315 has no affinity (Sugino et al., 1993). Considering the strong interaction of activin with follistatin, the basement membranes of cells containing heparan sulphate proteoglycans are potentially major stores of both activin and follistatin. Supporting this concept is the rapid and robust release of activin $A$ and follistatin by heparin in the circulation of patients undergoing cardiovascular procedures (Phillips et al., 2000). Moreover, the association with cell surfaces promotes endocytotic degradation of the activin-follistatin complex in rat pituitary cells (Hashimoto et al., 1997).

Follistatin also binds to $\alpha_{2}$-macroglobulin (Phillips et al., 1997), but the significance of this property is still unclear. In addition, mRNA of a newly recognized BMP binding protein, Ep45, when microinjected into Xenopus embryos, blocks the ability of follistatin to suppress BMP activity, whereas it has no effect on the other BMP antagonists, chordin and noggin (lemura et al., 1999).

\section{Differences between follistatin isoforms}

The only difference in structure between follistatin288 and follistatin-315 is the additional 27 amino acids at the carboxyl terminal end of follistatin-315. Does this distinguish the functions of the isoforms in some important way? Why is this alternative mRNA splicing event for follistatin conserved in mammals (Shimasaki et al., 1988a,b; Michel et al., 1990)? Unfortunately, current knowledge on the difference between the follistatin isoforms is far from complete.

Are both follistatin isoforms distributed in similar amounts and at identical locations in tissues? For determination of the relative expression of pre-follistatin 344 mRNA and pre-follistatin 317 mRNA, S1-nuclease analysis of total RNA from rat tissues, including kidney, pancreas, uterus, muscle, lung, testis, cortex, thymus, pituitary, adrenal, heart and ovary, has demonstrated that pre-follistatin $317 \mathrm{mRNA}$ is expressed at less than $5 \%$ of pre-follistatin 344 mRNA (Michel et al., 1990). It is unclear whether the relative ratio between the amounts of follistatin-288 and follistatin-315 is finely regulated and crucial to normal function in diverse systems. Follistatin288 is the predominant form present in human follicular fluid, whereas the main form in serum is follistatin315 (Schneyer et al., 1996). This finding, together with the fact that the cell surface and the extracellular matrix are rich in heparan sulphate proteoglycans to which follistatin-288 binds with much higher affinity than follistatin-315 (Sugino et al., 1993), indicates that follistatin-288 is primarily a membrane-bound form of follistatin, whereas follistatin-315 is a circulating form. The distinct difference between the amounts of follistatin288 and follistatin-315 in different locations implies different biological roles of the follistatin isoforms.

Do both follistatin isoforms have similar affinity for activins or neutralizing ability for activins? Follistatin-288 is approximately 10 -fold more potent than follistatin315 in suppressing FSH secretion from the rat pituitary cells in vitro (Inouye et al., 1991). Furthermore, all six molecular species of follistatin purified from pig ovaries have similar activin binding activity $\left(K_{\mathrm{d}}=540-680 \mathrm{pmol}\right.$ $\left.\mathrm{I}^{-1}\right)$. However, the $\mathrm{COOH}$-terminal truncated form, follistatin-288, shows much higher affinity for the rat granulosa cell surface than follistatin-303, and follistatin315 has no affinity. Follistatin-288 is more potent in suppressing pituitary $\mathrm{FSH}$ release than follistatin303 and follistatin-315 (Sugino et al., 1993), and another study using heparan sulphate purified from Xenopus embryos supports a higher affinity of follistatin288 for heparan sulphate than that of follistatin-315 (Yamane et al., 1998). Through its binding to ${ }^{125} \mathrm{I}$ labelled activin A, follistatin-288 is able to accelerate the endocytotic internalization and lysosomal degradation of activin by pituitary cells (Hashimoto et al., 1997). In contrast, follistatin-315 does not show this action. These observations together indicate that the difference between follistatin-288 and follistatin-315 in suppressing pituitary FSH secretion is due to their different capacities 
to neutralize activin. However, Hashimoto et al. (2000), using surface plasmon resonance and affinity crosslinking, indicated an alternative explanation. First, the inhibitory effect of follistatin-288 on activin-induced transcriptional responses is more potent than that of follistatin-315 in the presence or absence of heparan sulphates. Second, follistatin-288 prevents activin from binding to its type II receptor more completely than does follistatin-315. Furthermore, there is a 10-fold difference in the $K_{d}$ value of follistatin-288 and follistatin-315 for activin $A$. These observations led to the conclusion that the activin-neutralizing activity of follistatin isoforms is dependent on their affinity for activin.

Do both follistatin isoforms exert similar functions and effects in diverse tissues? Comprehensive studies addressing this particular question are lacking in the literature. In the rat pituitary cell in vitro system, follistatin-288 promotes proteolytic degradation, whereas activin-follistatin-315 complexes resist endocytotic and proteolytic degradation and are relatively more stable (Hashimoto et al., 1997). Together with the different distribution and binding affinities of follistatin288 and follistatin-315 (Michel et al., 1990; Schneyer et al., 1996; Hashimoto et al., 2000), follistatin-315 may act as a reservoir for activin, to prevent activin from proteolysis locally and to help regulate the distribution, function and activity of activin in various tissues and bodily fluids (Delbaere et al., 1999; McPherson et al., 1999). Alternatively, follistatin-315 may bind and neutralize the actions of activin resulting from 'over production' at local sites. Whether there are mechanisms to permit the dissociation of activin from follistatin-315 to exert its biological effects remains unclear, as the binding of activins to follistatin is claimed to be almost irreversible (Schneyer et al., 1996).

\section{Follistatins in ovary}

Folliculogenesis in mammals can be divided into two distinct periods: the gonadotrophin-independent (preantral) and gonadotrophin-dependent (antral or Graafian) periods. Responding to cyclic pituitary gonadotrophin secretion, the various follicular compartments interact in a highly integrated manner to secrete sex steroids and to produce a fertilizable ovum. Apart from being regulated by pituitary gonadotrophins, folliculogenesis is also modulated by various intraovarian growth factors, especially in the preantral stage. These growth factors include epidermal growth factor (EGF), fibroblast growth factor (FGF), TGF- $\alpha$, TGF- $\beta$, insulin-like growth factors (IGFs), IGF-binding proteins (IGFBPs), GDF-9, BMPs, inhibins, activins and follistatins (Webb et al., 1999; Elvin et al., 2000). The role of the follistatins in ovarian function is related to the manner by which they function through interactions with some members of the TGF- $\beta$ superfamily, that is activins, GDF-9 and BMPs.

\section{Location and secretion of follistatin}

Within the ovary, the granulosa cells in antral follicles and luteinized granulosa cells are the main sites that express follistatin mRNA and protein, whereas other structures, such as the theca cells, stroma and oocytes, appear to be devoid of follistatin mRNA (Shimasaki et al., 1989; Roberts et al., 1993; Braw-Tal, 1994; Tisdall et al., 1994), although follistatin mRNA has been observed in human oocytes (Sidis et al., 1998). However, follistatin protein was detected in the theca cell layers of human small antral follicles in the absence of follistatin mRNA expression, but then became undetectable with the development of a dominant follicle (Roberts et al., 1993). Thus, the granulosa cells are the type of cell in the ovary responsible for producing and secreting follistatin in most species. It is important to note that the level of follistatin mRNA expression within the ovary depends on the developmental stages of follicles. Follistatin mRNA expression within the antral follicles increases as follicular maturation progresses and declines during the atretic process (Roberts et al., 1993; Lindsell et al., 1994). Moreover, the follistatin protein appears to be present in only the selected dominant follicles (Nakatani et al., 1991). At the same time, primordial through to primary follicles do not express follistatin mRNA (Kogawa et al., 1991; Braw-Tal, 1994; Tisdall et al., 1994), implying that follistatin may not be involved in the initial stage of recruitment of follicles. Species differences occur, as the expression of follistatin is maintained in the corpus luteum in primates, whereas in other species, expression falls markedly after ovulation in the developing corpus luteum (Kogawa et al., 1991; Roberts et al., 1993; Wada et al., 1996).

Follistatin expression in granulosa cells can be regulated through both cyclic AMP-dependent or protein kinase A (PKA) and protein kinase C (PKC) pathways (Miyanaga et al., 1993; Lindsell et al., 1994; Shukovski et al., 1995; Tano et al., 1995; Tuuri et al., 1996). FSH, an activator of the PKA pathway, stimulates inhibin but not activin production, whereas $\mathrm{GnRH}$, an activator of the PKC pathway, stimulates activin, and to a lesser extent, inhibin production. Both FSH and $\mathrm{GnRH}$ enhance follistatin protein production in an additive manner (Miyanaga et al., 1993).

The extent of differentiation of granulosa cells may influence follistatin production in response to $\mathrm{FSH}$, $\mathrm{LH}$ and activin A. FSH enhances follistatin production in vitro by undifferentiated and partially differentiated granulosa cells, but not by fully differentiated granulosa cells. In contrast, the only detectable effect of $\mathrm{LH}$ on follistatin production is on partially differentiated granulosa cells. Activin A promotes follistatin production by undifferentiated and partially differentiated granulosa cells, but suppresses follistatin production by fully differentiated granulosa cells (Shintani et al., 1997). Moreover, an in vivo study in rats indicated that 
Table 1. The antagonism between activin and follistatin in the ovary

\begin{tabular}{|c|c|c|c|c|}
\hline & Granulosa cells & $\begin{array}{l}\text { Numbers of FSH and LH } \\
\text { receptors in granulosa cells }\end{array}$ & Steroidogenesis & Oocytes \\
\hline Activin & $\begin{array}{l}\uparrow \text { Differentiation } \\
\downarrow \text { Premature luteinization }\end{array}$ & $\uparrow$ & $\begin{array}{l}\uparrow \mathrm{E}_{2} \\
\uparrow \mathrm{P}_{4} \text { in undifferentiated granulosa cells } \\
\downarrow \mathrm{P}_{4} \text { in differentiated granulosa cells } \\
\downarrow \text { Androgen }\end{array}$ & $\begin{array}{l}\uparrow \text { Meiotic and cytoplasmic } \\
\text { maturation } \\
\uparrow \text { Developmental competence } \\
\text { to form blastocysts }\end{array}$ \\
\hline Follistatin & $\uparrow$ Luteinization or atresia & $\downarrow$ & $\begin{array}{l}\downarrow E_{2} \\
\downarrow P_{4} \text { in undifferentiated granulosa cells } \\
\uparrow P_{4} \text { in differentiated granulosa cells } \\
\uparrow \text { Androgen }\end{array}$ & $\begin{array}{l}\downarrow \text { Meiotic and cytoplasmic } \\
\quad \text { maturation } \\
\downarrow \text { Developmental competence } \\
\text { to form blastocysts }\end{array}$ \\
\hline
\end{tabular}

$E_{2}$ : oestrogen; $P_{4}$ : progesterone; $\uparrow:$ increase or promote; $\downarrow$ : decrease or inhibit.

the expression of follistatin in preovulatory follicles might be suppressed by the primary gonadotrophin surge during pro-oestrus (Ogawa et al., 1994). Hence, the decrease of follistatin production in preovulatory follicles may occur before ovulation, possibly due to the primary gonadotrophin surge. Nevertheless, whether this phenomenon is crucial to the ovulation process needs further research. Other stimulators of ovarian follistatin in vitro include EGF and prostaglandin oestrogen (Lindsell et al., 1993; Tano et al., 1995; Tuuri and Ritovs, 1995; Shintani et al., 1997). In addition, the stimulation of follistatin production by FSH can be suppressed by EGF but enhanced by activin (Michel et al., 1992). Follistatin also antagonizes the action of activin on follistatin mRNA production (Tano et al., 1995), indicating that a local regulatory loop may be present in the granulosa cells.

\section{Effects of over-expression of follistatin on ovarian function}

Follistatin-deficient mutants died soon after birth, making it difficult to study ovarian function in that model (Matzuk et al., 1995). However, over-expression of mouse follistatin results in reproductive defects in transgenic mice (Guo et al., 1998). In this study, a mouse metallothionein-I promoter was fused to a $5.1 \mathrm{~kb}$ genomic fragment, resulting in over-expression of mouse follistatin transgene in many tissues of several lines. In line 4, a highly expressing line, FSH concentrations were significantly suppressed and histological analysis showed small ovaries with a block in folliculogenesis. It seems likely that the decreased FSH results from the blocking of FSH stimulation by activin. It is unclear whether this phenotype represents purely the effects of FSH deficiency or whether there is a direct effect of the increased follistatin expression. Nevertheless, in lines 9 and 5 , in which follistatin was moderately over-expressed and in which the FSH concentration was not suppressed, there was still some disruption in folliculogenesis. The phenotypes ranged from subfertility, a block at the stage of the early antral follicle, to a block at the stage of the early primary follicle. Hence, the results also underline the importance of follistatin in ovarian function.

\section{Interaction with activins}

The distribution of follistatin and the inhibin-activin subunits in the ovary have provided insights into their actions (Table 1). Neither $\beta A$ nor $\beta B$ mRNA is detectable in oocytes, but the $\alpha$ subunit mRNA is weakly detectable in some human oocytes (Sidis et al., 1998). The $\alpha$ subunit is present in granulosa cells and theca cells of antral follicles, and in luteinized granulosa cells, but not in luteinized theca cells (Roberts et al., 1993; Mather et al., 1997; Sidis et al., 1998). The $\beta A$ subunit mRNA and protein is observed in granulosa cells of all stages and theca cells of developing dominant follicles, whereas the $\beta B$ subunit is found only in granulosa cells of small antral follicles. In addition, the transcripts for all four activin receptor subtypes (ActRIA, ActRIB, ActRIIA and ActRIIB) are detectable in oocytes, granulosa cells and theca cells. Thus, generally inhibins and activins appear to be produced by granulosa cells and exert both autocrine and paracrine actions. As granulosa cells are also the main source of follistatin in the ovary, these cells have the capacity to modulate the local actions of the activins and inhibins. The sites of localization indicate that follistatin and inhibin may play a role at the later stages of follicular development, whereas the activins exert their effects primarily at the early stages of follicular development (Roberts et al., 1993; Lindsell et al., 1994; Mather et al., 1997; Sidis et al., 1998) (Fig. 4). These studies also led to the hypothesis that the orderly transition from an activin-dominant to an inhibin-follistatin-dominant microenvironment is critical for dominant follicle development (Knight and Glister, 2001).

It is a generally accepted concept that activin, either alone or with $\mathrm{FSH}$, exerts an autocrine effect on granulosa cells, promoting differentiation during the preantral and early antral stages of folliculogenesis and inhibiting premature luteinization at the later stages of antral follicle 


\section{The effects of TGF- $\beta$ superfamily members and follistatin in folliculogenesis}

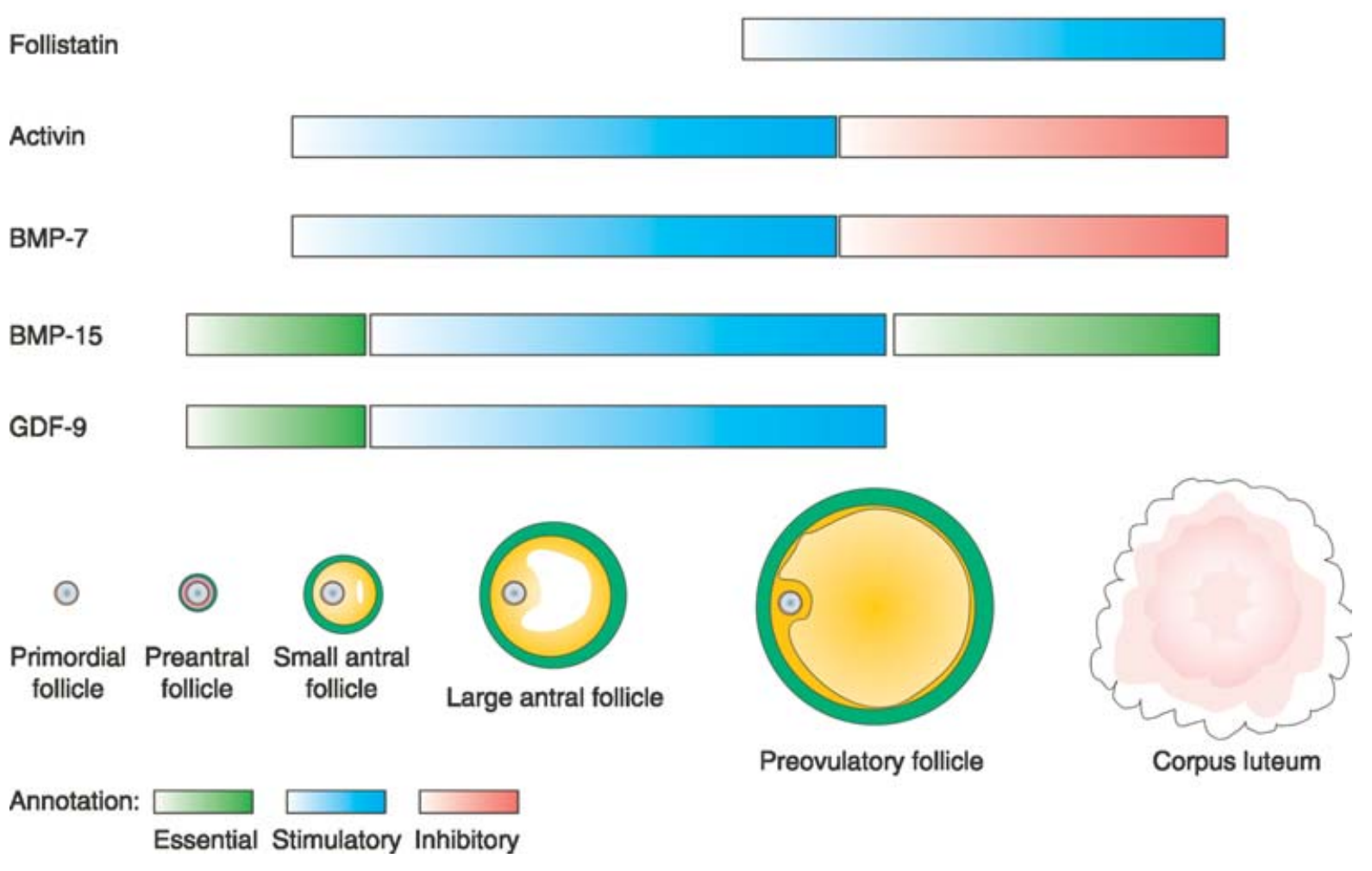

Fig. 4. The effects of follistatin and transforming growth factor $\beta$ (TGF- $\beta$ ) superfamily members on folliculogenesis. Activin facilitates the proliferation of granulosa cells and follicular growth from the stage of antral follicles, whereas it suppresses the formation of the corpus luteum. Follistatin plays its main role at the later stage of folliculogenesis and promotes the process of luteinization. Bone morphogenetic protein 7 (BMP-7) has similar effects to those of activin in folliculogenesis. BMP-15 and growth differentiation factor 9 (GDF-9) are both essential for the further growth of preantral follicles. In addition, BMP-15 is associated with ovulation.

development. Follistatin, on the other hand, modulates the function of granulosa cells in favour of luteinization or atresia by neutralizing the actions of activin and may also directly modulate progesterone metabolism by granulosa cells (Findlay, 1993; Li et al., 1995; Miro and Hillier, 1996). However, the stimulatory action of activin on the proliferation of granulosa cells may be stage-specific (Yokota et al., 1997; Liu et al., 1998; Mizunuma et al., 1999). Activin A has no effect on preantral follicles from adult mice and blocks $\mathrm{FSH}$ stimulated follicular growth, although activin A enhances preantral follicular growth in immature mice (Yokota et al., 1997). In addition, these authors showed that in vitro activin, secreted by secondary follicles, causes primary follicles to become dormant at the resting stage, an action reversed by follistatin (Mizunuma et al., 1999). Together, these findings indicate that activin and follistatin may regulate the initiation of folliculogenesis and determine the size of the cohort of growing follicles.

Activin stimulates the expansion of $\mathrm{FSH}$ and $\mathrm{LH}$ receptors on granulosa cells and follistatin antagonizes these actions but has no direct effect (Xiao et al., 1992; Tsuchiya et al., 1999). Activin, at a higher dose (100 ng $\mathrm{ml}^{-1}$ ), prevents $\mathrm{FSH}$-induced downregulation of numbers of FSH receptors; however, at lower concentrations (3-30 $\mathrm{ng} \mathrm{ml}^{-1}$ ) it enhances downregulation of numbers of $\mathrm{FSH}$ receptors by $20 \%$. Surprisingly, follistatin alone prevents $\mathrm{FSH}$-induced downregulation by increasing numbers of FSH receptors up to $40-50 \%$ (Xiao et al., 1992), perhaps blocking the action of endogenous activin or other TGF- $\beta$ family members. In rat granulosa cells, activin in the presence of FSH also induces $\mathrm{LH}$ receptor expansion significantly, and follistatin inhibits this effect in a dose-dependent manner (Tsuchiya et al., 1999). In summary, activin plays a pivotal role in the acquisition of responsiveness to $\mathrm{FSH}$ by granulosa cells of preantral follicles, an essential step for their further development that can be facilitated by the low expression of follistatin in small follicles.

The actions of activin and follistatin on steroidogenesis in granulosa cells vary according to the extent of maturity of granulosa cells (Fig. 5). In vitro studies involving 


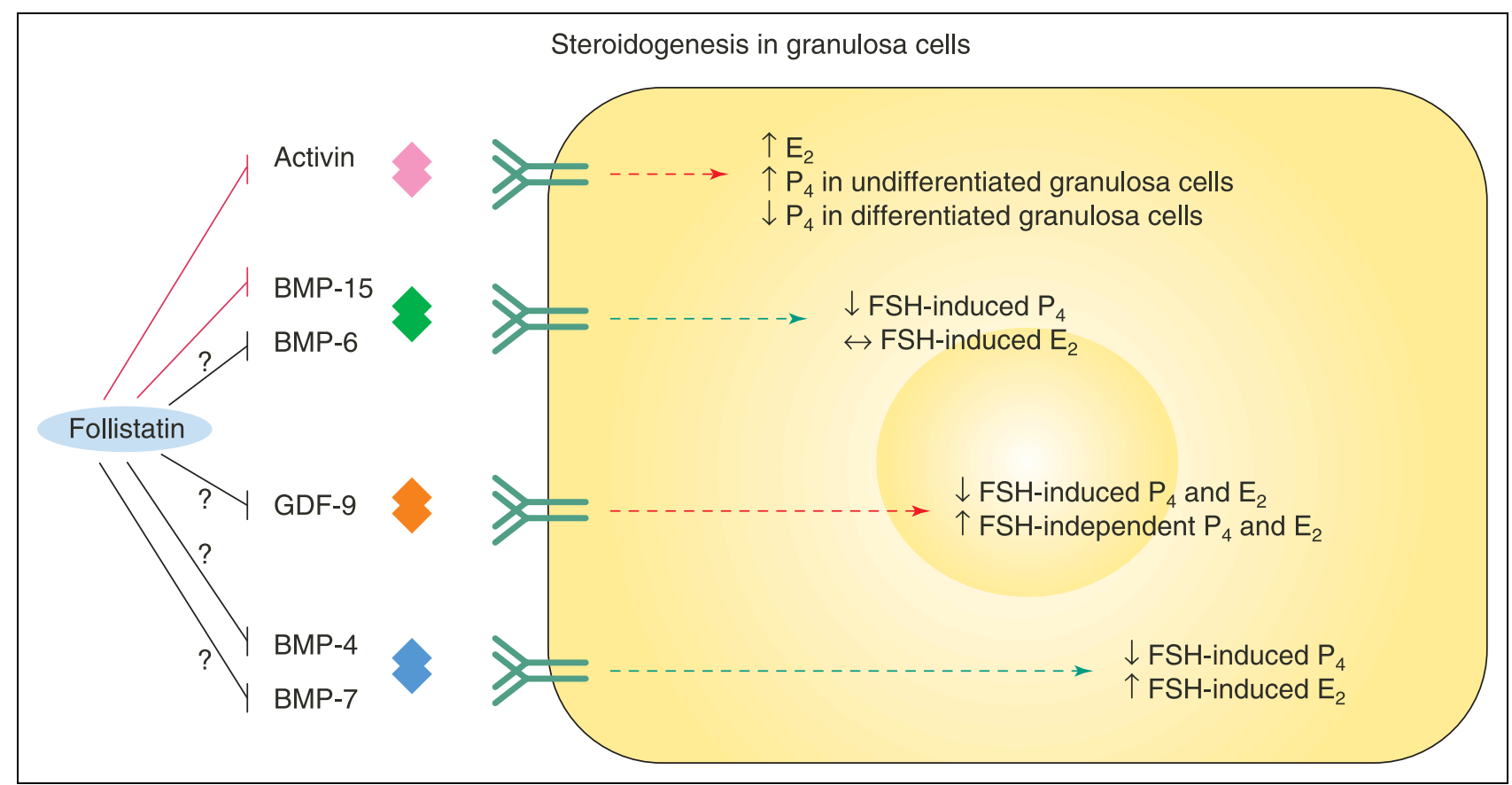

Fig. 5. Schematic presentation of the effects of some members of the transforming growth factor $\beta$ (TGF- $\beta$ ) superfamily and follistatin on steroidogenesis in granulosa cells. Follistatin antagonizes the actions of activin and bone morphogenetic protein 15 (BMP-15) on steroidogenesis in granulosa cells. $\mathrm{E}_{2}$ : oestrogen; $\mathrm{P}_{4}$ : progesterone; $\uparrow:$ enhance or promote; $\downarrow$ : suppress or inhibit; $\leftrightarrow:$ no effect; ?: no available mammalian data.

undifferentiated or partially differentiated granulosa cells have shown that activin enhances gonadotrophinstimulated P450 aromatase activity and oestradiol production, regardless of the developmental stage. However, activin promotes gonadotrophin-stimulated progesterone production in undifferentiated granulosa cells, whereas it suppresses this effect in partially differentiated granulosa cells (Miro et al., 1991; Shukovski et al., 1991; Hillier and Miro, 1993). Furthermore, in fully differentiated granulosa cells, activin suppresses gonadotrophin-stimulated P450scc expression and progesterone production (Miro et al., 1991; Cataldo et al., 1994), effects that can be antagonized by follistatin (Xiao et al., 1992; Cataldo et al., 1994). These findings indicate that activin stimulates the early differentiation of granulosa cells and retards the late differentiation and luteinization, whereas follistatin antagonizes these actions potentiating luteinization in mature granulosa cells.

The main role of theca cells is to synthesize androgen substrates for oestradiol production by granulosa cells. In studies on theca cells in humans, rats and cows, activin attenuates $\mathrm{LH}$-induced androgen production and suppresses the increase of androgen production stimulated by oestradiol, whereas follistatin reverses these effects (Hsueh et al., 1987; Hillier, 1991; Wrathall and Knight, 1995). In contrast, activin induces and follistatin inhibits the proliferation of theca cells (Duleba et al., 2001).
In vitro activin promotes and follistatin inhibits meiotic and cytoplasmic maturation of the oocytes (Alak et al., 1996, 1998). Furthermore, activin potentiates the development of blastocysts from denuded or cumulusenclosed bovine oocytes, whereas follistatin neutralizes these actions (Silva and Knight, 1998). Together, these findings indicate that activin and follistatin contribute to the regulation of oocyte maturation and competence.

\section{Interaction of follistatin with other members of the TGF- $\beta$ superfamily in the ovary}

Compelling evidence indicates that follistatin can influence ovarian function by binding to other members of the TGF- $\beta$ superfamily, especially BMPs (Yamashita et al., 1995; lemura et al., 1998; Otsuka et al., 2001a). Given the functions of GDF-9, BMP-15 (also known as GDF-9B), BMP-6, BMP-4 and BMP-7 in the ovary, follistatin potentially influences a number of the actions of these proteins (Table 2, Figs 4 and 5).

GDF-9, BMP-15 and BMP- 6 show between 28 and $53 \%$ homology and are expressed in oocytes within the ovary (Lyons et al., 1989; McGrath et al., 1995; Dube et al., 1998). Given the many actions of GDF-9 and BMP-15 on ovarian somatic cells, their role in follicular development is significant and confirms the bi-directional communication between oocytes and granulosa cells. In the ovaries of mice, cows and humans, 
Table 2. Actions of other transforming growth factor $\beta$ (TGF- $\beta$ ) superfamily members to which follistatin potentially binds in the ovary

\begin{tabular}{|c|c|c|c|c|c|}
\hline & Folliculogenesis & Granulosa cell & Theca cell & Steroidogenesis & Interaction with follistatin \\
\hline GDF-9 & $\begin{array}{l}\text { Deficiency in mouse: homozygous } \\
\text { mutants } \rightarrow \text { blocked at the stage of } \\
\text { primary follicles; abnormal } \\
\text { ultrastructural features of oocytes } \\
\text { Induce in vitro cumulus expansion }\end{array}$ & $\begin{array}{l}\uparrow \text { Proliferation (FSH-independent) } \\
\downarrow \text { FSH-induced differentiation }\end{array}$ & $\begin{array}{l}\text { Deficiency in mouse: } \\
\text { unable to recruit the } \\
\text { theca cell precursors }\end{array}$ & $\begin{array}{l}\uparrow \mathrm{FSH} \text {-independent } \mathrm{P}_{4} \text { and } \mathrm{E}_{2} \\
\quad \text { production } \\
\downarrow \mathrm{FSH} \text {-induced } \mathrm{P}_{4} \text { and } \mathrm{E}_{2} \\
\quad \text { production } \\
\downarrow \mathrm{FSH} \text {-induced } \mathrm{LH} \text { receptor } \\
\quad \text { production }\end{array}$ & $?$ \\
\hline \multirow[t]{2}{*}{ BMP-15 } & $\begin{array}{l}\text { Deficiency in sheep: homozygous } \\
\text { mutants } \rightarrow \text { blocked at the stage of } \\
\text { primary follicles; heterozygous } \\
\text { mutants } \rightarrow \text { increased ovulation }\end{array}$ & $\uparrow$ Proliferation (FSH-independent) & $?$ & $\begin{array}{l}\downarrow \mathrm{FSH} \text { receptor production } \\
\downarrow \mathrm{FSH} \text {-induced } \mathrm{FSH} \text { and } \mathrm{LH} \\
\quad \text { receptor production } \\
\downarrow \mathrm{FSH} \text {-induced } \mathrm{P}_{4} \text { production } \\
\leftrightarrow \mathrm{FSH} \text {-induced } \mathrm{E}_{2} \text { production }\end{array}$ & $\begin{array}{l}\downarrow \text { Effects of BMP-15 on the } \\
\text { proliferation, FSH receptor } \\
\text { and steroidogenesis }\end{array}$ \\
\hline & $\begin{array}{l}\text { Deficiency in mouse: homozygous } \\
\text { mutants } \rightarrow \text { subfertile, decreased } \\
\text { ovulation }\end{array}$ & & & & \\
\hline BMP-6 & $?$ & $\leftrightarrow$ Proliferation & $?$ & $\begin{array}{l}\downarrow \mathrm{FSH} \text {-induced } \mathrm{P}_{4} \text { production } \\
\leftrightarrow \mathrm{FSH} \text {-induced } \mathrm{E}_{2} \text { production }\end{array}$ & $?$ \\
\hline BMP-4 & $?$ & $?$ & $?$ & $\begin{array}{l}\uparrow \mathrm{FSH} \text {-induced } \mathrm{E}_{2} \text { production } \\
\downarrow \mathrm{FSH} \text {-induced } \mathrm{P}_{4} \text { production }\end{array}$ & $?$ \\
\hline BMP-7 & $\begin{array}{l}\uparrow \text { Follicular growth } \\
\downarrow \text { Ovulation and luteinization }\end{array}$ & $\uparrow$ Proliferation & $?$ & $\begin{array}{l}\uparrow \mathrm{FSH} \text {-induced } \mathrm{E}_{2} \text { production } \\
\downarrow \mathrm{FSH} \text {-induced } \mathrm{P}_{4} \text { production }\end{array}$ & $?$ \\
\hline
\end{tabular}

BMP: bone morphogenetic protein; $\mathrm{E}_{2}$ : oestrogen; GDF: growth differentiation factor; $\mathrm{P}_{4}$ : progesterone; $\uparrow$ : enhance or promote; $\downarrow$ : suppress or inhibit; $\leftrightarrow:$ no effect; ?: no available mammalian data. 
GDF-9 and BMP-15 mRNA or protein are found in the oocytes of small primary follicles, but not in the primordial follicles (Elvin et al., 2000). However, in cows and pigs, expression of GDF-9 is low in oocytes of primordial follicles (Bodensteiner et al., 1999), and in humans, GDF-9 precedes the expression of BMP15 (Aaltonen et al., 1999). In all subsequent steps of folliculogenesis, both BMP-15 and GDF-9 are present (Elvin et al., 2000). However, the interactions between follistatin and GDF-9 and BMP-15 would not occur in small follicles as follistatin is only expressed in granulosa cells of larger follicles.

Folliculogenesis in GDF-9-deficient mice does not proceed beyond the type $3 \mathrm{~b}$ (primary) follicle (Dong et al., 1996), despite increased serum FSH and $\mathrm{LH}$ concentrations. The granulosa cells cease proliferation and undergo apoptosis and are unable to recruit theca cell precursors to form a theca layer surrounding the follicle (Elvin et al., 1999a). The GDF-9-deficient oocytes show perinuclear organelle aggregation, unusual peripheral Golgi complexes, fail to form cortical granules and show altered interconnections between granulosa cells and oocytes, together indicating abnormal cytoplasmic maturation of oocytes and granulosa cells. Northern blot analysis shows increased kit ligand expression and decreased inhibin-activin $\beta B$ and follistatin expression in these GDF-9-deficient ovaries (Elvin et al., 1999a), through mechanisms yet to be defined. Recombinant mouse GDF-9 (Elvin et al., 1999b) induces hyaluronan synthase 2 (HAS2), cyclooxygenase 2 (COX-2), and steroidogenic acute regulator protein (StAR) mRNA synthesis but suppresses urokinase plasminogen activator (UPA) and LHR mRNA synthesis in cultured mouse granulosa cells. Consistent with the induction of StAR mRNA, recombinant GDF-9 enhances granulosa cell progesterone synthesis in the absence of $\mathrm{FSH}$ and, through its action on HAS2 and UPA, induces cumulus expansion of oocytectomized cumulus cell-oocyte complexes and the production of the hyaluronic acidrich extracellular matrix during cumulus expansion. Treatment with recombinant GDF-9, but not FSH, can stimulate proliferation of cultured rat granulosa cells from both early antral and preovulatory follicles, probably by decreasing cAMP production (Vitt et al., 2000), stimulating basal steroidogenesis in granulosa cells but attenuating $\mathrm{FSH}$-stimulated progesterone and oestradiol production and $\mathrm{LH}$ receptor formation (Vitt et al., 2000).

BMP-15 is a potent stimulator of FSH-independent granulosa cell proliferation (Otsuka et al., 2000). Although it has no effect on steroidogenesis, BMP-15 alone suppresses $\mathrm{FSH}$-induced progesterone production, but has no effect on oestradiol production (Otsuka et al., 2000). Importantly, BMP-15 markedly suppresses both the basal and $\mathrm{FSH}$-induced increases in the abundance of $\mathrm{FSH}$ receptor $\mathrm{mRNA}$, indicating that this action may be the primary effect of BMP-15 in suppressing $\mathrm{FSH}$ action (Otsuka et al., 2001b). The importance of BMP-
15 in folliculogenesis is supported by the block at the stage of primary follicles in BMP-15 homozygous sheep, features similar to the phenotype of GDF-9 deficiency (Galloway et al., 2000). In contrast, BMP-15 heterozygous mutants of sheep have increased ovulation and multiple pregnancies. However, inactivation of the BMP-15 gene in mice (BMP-15-/-) did not cause the same phenotype as that in sheep (Yan et al., 2001), as the ovaries were grossly indistinguishable from either heterozygous (BMP-15 $5^{+-}$) or wild-type ovaries. Nonetheless, BMP-15-/- females were subfertile and had decreased ovulation and fertilization rates. These findings indicate that the dosage of intact BMP-15 and GDF-9 alleles influences the destiny of oocytes and subsequent fertility (Yan et al., 2001).

Unlike BMP-15 and GDF-9, BMP-6, another oocytederived growth factor, has no effect on the mitogenic activity of rat granulosa cells (Otsuka et al., 2001c), although it suppresses $\mathrm{FSH}$-induced progesterone production but not oestradiol production. BMP-6 also exerts a similar action to BMP-15 by suppressing $\mathrm{FSH}$ regulated progesterone and oestradiol production. This action probably occurs through the downregulation of adenylate cyclase activity, in contrast to BMP-15, which suppresses the basal FSH receptor expression (Otsuka et al., 2001c).

Although there are no reports describing the interaction between follistatin and GDF-9 or BMP-6, follistatin binds BMP-15 in surface plasmon resonance studies (Otsuka et al., 2001a) and inhibits BMP-15induced thymidine uptake by rat granulosa cells in vitro, but is ineffective directly. Follistatin also reverses the suppressive effect of BMP-15 on FSH receptor expression and $\mathrm{FSH}$-induced progesterone production. These data clearly broaden the roles of follistatin in the ovary and given the high structural identity between GDF-9 and BMP-15 make it very likely that follistatin also binds to GDF-9 and modulates its function.

Yamashita et al. (1995) reported the binding and neutralization of BMP-2, BMP-4, BMP-7 and 4/7 heterodimers by follistatin in Xenopus embryos, but no data are available for mammalian species. In contrast to GDF-9, BMP-15 and BMP-6, which are expressed by oocytes, the transcripts of BMP-4 and BMP-7 have been detected prominently in theca cells (Shimasaki et al., 1999). In situ hybridization histochemistry identified strong mRNA labelling for BMP-4 and -7 in the theca cells and BMP receptor types $\mathrm{IA}, \mathrm{IB}$, and $\mathrm{II}$ in the granulosa cells and oocytes of most follicles in ovaries of normal cyclic rats, indicating potential paracrine mechanisms of BMP-4 and -7 within the ovary. Further in vitro studies showed that BMP-4 and -7 differentially modulated FSH actions in rat granulosa cells, enhancing $\mathrm{FSH}$-induced oestradiol and suppressing progesterone production (Shimasaki et al., 1999). In general, BMP-7 appears to promote follicular growth and development, while simultaneously suppressing ovulation and luteinization (Lee et al., 2001). 
Further studies are required to clarify the interactions between follistatin and BMP-4 and -7 and to determine their physiological relevance within the mammalian ovary.

\section{Interactions among members of the TGF- $\beta$ superfamily}

Although follistatin interacts with several members of the TGF- $\beta$ superfamily, it is also important to note that interactions may occur between these growth factors in the control of ovarian function. These actions could occur at three levels. First, they may occur at the receptor level. As there is a high extent of identity of TGF- $\beta$ superfamily members, it is likely that different members bind to the same receptor, resulting in competitive effects. For example, activin and BMP-7 bind to the same type II receptors, ActRII and ActRIIB (Macias-Silva et al., 1998).

Second, these interactions may occur from crosstalk between the signalling pathways of TGF- $\beta$ superfamily members. For example, signalling by activin and BMP$2 / 4$ has been shown to interact antagonistically. In Xenopus ectodermic explants, activin induces dorsaltype mesoderm, whereas BMP-2/4 induces ventral mesoderm and blocks the dorsal mesoderm-inducing activity of activin. Investigation of the mechanisms underlying this phenomenon has revealed that this antagonism between activin and BMP-2/4 may be explained by intracellular competition for a limited pool of SMAD4, under certain physiological situations (Candia et al., 1997). It has been proposed that SMAD4 is limiting in cells, hence the simultaneous activation of two signalling pathways could cause competitive effects. The outcome of this competition may dictate the ultimate signals. Another example is BAMBI (BMP and activin membranebound inhibitor; Onichtchouk et al., 1999), which is induced by BMP signalling and inhibits not only BMP signalling, but also activin and TGF- $\beta$ signalling.

Finally, these interplays may occur indirectly via the interactions of factors, the amounts of which are regulated by TGF- $\beta$ superfamily members. In other words, some TGF- $\beta$ superfamily members may not only interplay with each other directly, but also regulate the same factors, for example sex steroids (Miro et al., 1991; Shukovski et al., 1993; Alak et al., 1998; Shimasaki et al., 1999; Dooley et al., 2000; Otsuka et al., 2001c). Thus, the physiological activities of these TGF- $\beta$ superfamily members arise from the net stimulatory or inhibitory inputs that impinge upon downstream targets, such as sex steroids. On the basis of the concepts mentioned here, follistatin functions in a multidimensional network, not just a simple linear system.

\section{Conclusion}

As follistatin can bind to activin and neutralize its activity (Nakamura et al., 1990), and given the widespread actions of activin in regulating cellular homeostasis (divide or die), differentiation (at fetal and adult stages) and hormonal homeostasis (the balance among hormones), follistatin plays a significant role in diverse areas of biology. In the area of reproduction, a wealth of evidence indicates that follistatin plays a significant role in the pituitary, ovary and testis in an autocrine or paracrine fashion, and that most of follistatin biology may be explained by its antagonism with activin. However, there is evidence to indicate that follistatin binds to other members of the TGF- $\beta$ superfamily, modulating their functions in a manner analogous to activin. Hence, follistatin has been shown to be able to bind to BMPs and antagonize their effects in Xenopus embryos (Yamashita et al., 1995; Fainsod et al., 1997; lemura et al., 1998). Follistatin has also been shown to have the capacity to inhibit the action of myostatin, which is another TGF- $\beta$ superfamily member and acts as a negative regulator of skeletal muscle mass (Lee and McPherron, 2001). In addition, follistatin is able to bind and suppress the activities of BMP-15 in the ovary (Otsuka et al., 2001a). These findings open a new window of opportunity to assess the role of follistatin in ovarian functions. What is less clear is whether the role of follistatin in regulating the biology of the TFG- $\beta$ superfamily ligands is simply dictated by the local concentration of follistatin. This appears unlikely given the complexity of the systems we have described. However, to date few regulators of follistatin function have been reported (lemura et al., 1999).

Amthor et al. (2002) showed that in the development of chick limbs, follistatin not only binds to BMP-7 in muscle, but also appears to be able to monitor and refine the concentration of BMP-7 in a way that promotes muscle growth. This finding also implicates some potential roles of follistatin in maintaining homeostasis in the body. Moreover, members of the TGF- $\beta$ superfamily may act antagonistically or synergistically with each other. For example, BMP-3 is a negative regulator of bone density, opposing osteogenic activity displayed by other BMPs (Daluiski et al., 2001); antagonistic actions of activin and BMP-2/4 exist during early embryogenesis of Xenopus (Kaufmann et al., 1996; Candia et al., 1997); and GDF-9 and BMP-15 exert their activities synergistically in the ovary (Yan et al., 2001). Collectively, the findings indicating that follistatin could bind to other TGF- $\beta$ superfamily ligands besides activin and the interplay that exists among these ligands, led to the idea that the role of follistatin in biology may be much more complex than initially predicted.

Activin and BMP-2,-4 are considered to function as morphogens during Xenopus development (Gurdon and Bourillot, 2001). Morphogens are defined as secreted signalling molecules that form a concentration gradient from a localized source and induce different cell fates of surrounding cells according to the local concentration of a morphogen perceived by the cells. Thus, morphogens can organize a field of surrounding 
cells into patterns. However, these gradient-dependent activities of morphogens may be produced in another way (Dale and Wardle, 1999). The morphogens may be secreted locally in the entire field and a gradient of morphogen activity can be formed by the modulation of its activity by an inhibitor of the morphogen due to the long-range diffusion of the inhibitor from a localized source. In such a manner, follistatin may play a role as an inhibitor of morphogens that are members of the TGF- $\beta$ superfamily. However, it is unclear whether this graded molecular information exists or plays a role in folliculogenesis. Some in vitro or in vivo experiments may be designed to answer this question.

Given that the vast majority of the results were generated from in vitro studies that may not mimic a physiological situation, to explore such a complex system in follistatin biology, it is necessary to establish appropriate in vivo models for research. For example, in vivo models that can separate the actions of the two isoforms of follistatin and also in vivo models that can manipulate the ratio of two follistatin isoforms would further enhance our understanding of follistatin biology. Moreover, in vivo models that can manipulate the levels of follistatin and other members of the TGF- $\beta$ superfamily may be able to depict the networks in which follistatin functions.

Shyr-Yeu Lin is a holder of Monash Graduate Scholarship. This work is supported by a Program Grant from the National Health and Medical Research Council of Australia.

\section{References}

Key references are identified by asterisks.

Aaltonen J, Laitinen MP, Vuojolainen K et al. (1999) Human growth differentiation factor 9 (GDF-9) and its novel homolog GDF-9B are expressed in oocytes during early folliculogenesis Journal of Clinical Endocrinology and Metabolism 84 2744-2750

Alak BM, Smith GD, Woodruff TK, Stouffer RL and Wolf DP (1996) Enhancement of primate oocyte maturation and fertilization in vitro by inhibin A and activin A Fertility and Sterility 66 646-653

Alak BM, Coskun S, Friedman CI, Kennard EA, Kim MH and Seifer DB (1998) Activin A stimulates meiotic maturation of human oocytes and modulates granulosa cell steroidogenesis in vitro. Fertility and Sterility $701126-1130$

Amthor H, Christ B, Rashid-Doubell F, Kemp CF, Lang E and Patel K (2002) Follistatin regulates bone morphogenetic protein-7 (BMP-7) activity to stimulate embryonic muscle growth Developmental Biology 243 115127

Bodensteiner KJ, Clay CM, Moeller CL and Sawyer HR (1999) Molecular cloning of the ovine growth/differentiation factor-9 gene and expression of growth/differentiation factor-9 in ovine and bovine ovaries Biology of Reproduction 60 381-386

Böttner M, Krieglstein K and Unsicker K (2000) The transforming growth factor- $\beta$ s: structure, signalling, and roles in nervous system development and functions Journal of Neurochemistry 75 2227-2240

Braw-Tal R (1994) Expression of mRNA for follistatin and inhibin/activin subunits during follicular growth and atresia Journal of Molecular Endocrinology 13 253-264

Candia AF, Watabe T, Hawley SH, Onichtchouk D, Zhang Y, Derynck R, Niehrs C and Cho KW (1997) Cellular interpretation of multiple TGFbeta signals: intracellular antagonism between activin/BVg1 and BMP2/4 signaling mediated by Smads Development 124 4467-4480
Cataldo NA, Rabinovici J, Fujimoto VY and Jaffe RB (1994) Follistatin antagonizes the effects of activin-A on steroidogenesis in human luteinizing granulosa cells Journal of Clinical Endocrinology and Metabolism 79 272-277

Dale L and Wardle FC (1999) A gradient of BMP activity specifies dorsal-ventral fates in early Xenopus embryos Seminars in Cell and Developmental Biology 10 319-326

Daluiski A, Engstrand T, Bahamonde ME, Gamer LW, Agius E, Stevenson SL, Cox K, Rosen V and Lyons KM (2001) Bone morphogenetic protein-3 is a negative regulator of bone density Nature Genetics 27 84-88

Daopin S, Piez KA, Ogawa Y and Davies DR (1992) Crystal structure of transforming growth factor- $\beta 2$ : an unusual fold for the superfamily Science 257 369-373

de Groot E, Veltmaat J, Caricasole A, Defize L and van den Eijnden-van Raaij A (2000) Cloning and analysis of the mouse follistatin promoter Molecular Biology Reports 27 129-139

de Winter JP, ten Dijke P, de Vries CJ, van Achterberg TA, Sugino H, de Waele $P$, Huylebroeck $D$, Verschueren $K$ and van den Eijnden-van Raaij AJ (1996) Follistatins neutralize activin bioactivity by inhibition of activin binding to its type II receptors Molecular and Cellular Endocrinology 116 105-114

Delbaere A, Sidis Y and Schneyer AL (1999) Differential response to exogenous and endogenous activin in a human ovarian teratocarcinomaderived cell line (PA-1): regulation by cell surface follistatin Endocrinology 140 2463-2470

DePaolo LV (1997) Inhibins, activins, and follistatins: the saga continues Proceedings Society for Experimental Biology and Medicine 214328 339

Derynck R, Zhang Y and Feng X-H (1998) Smads: transcriptional activators of TGF-b responses Cell $\mathbf{9 5} 737-740$

Dong J, Albertini DF, Nishimori K, Kumar TR, Lu N and Matzuk MM (1996) Growth differentiation factor-9 is required during early ovarian folliculogenesis Nature 383 531-535

Dooley CA, Attia GR, Rainey WE, Moore DR and Carr BR (2000) Bone morphogenetic protein inhibits ovarian androgen production Journal of Clinical Endocrinology and Metabolism 85 3331-3337

Dube JL, Wang P, Elvin J, Lyons KM, Celeste AJ and Matzuk MM (1998) The bone morphogenetic protein 15 gene is $\mathrm{X}$-linked and expressed in oocytes Molecular Endocrinology 12 1809-1817

Duleba AJ, Pehlivan T, Carbone R and Spaczynski RZ (2001) Activin stimulates proliferation of rat ovarian thecal-interstitial cells Biology of Reproduction 65 704-709

Elvin JA, Yan C, Wang P, Nishimori K and Matzuk MM (1999a) Molecular characterization of the follicle defects in the growth differentiation factor 9-deficient ovary Molecular Endocrinology 13 1018-1034

Elvin JA, Clark AT, Wang P, Wolfman NM and Matzuk MM (1999b) Paracrine actions of growth differentiation factor-9 in the mammalian ovary Molecular Endocrinology 13 1035-1048

Elvin JA, Yan C and Matzuk MM (2000) Oocyte-expressed TGF$\beta$ superfamily members in female fertility Molecular and Cellular Endocrinology 159 1-5

Esch FS, Shimasaki S, Mercado M, Cooksey K, Ling N, Ying S, Ueno N and Guillemin R (1987) Structural characterization of follistatin: a novel follicle-stimulating hormone release-inhibiting polypeptide from the gonad Molecular Endocrinology 1 849-855

Fainsod A, Deissler K, Yelin R, Marom K, Epstein M, Pillemer G, Steinbeisser $\mathbf{H}$ and Blum $\mathbf{M}$ (1997) The dorsalizing and neural inducing gene follistatin is an antagonist of BMP-4 Mechanisms of Development 63 39-50

Fang J, Yin W, Smiley E, Wang SQ and Bonadio J (1996) Molecular cloning of the mouse activin $\beta E$ subunit gene Biochemical and Biophysical Research Communications 228 669-674

Feijen A, Goumans MJ and van den Eijnden-van Raaij AJ (1994) Expression of activin subunits, activin receptors and follistatin in postimplantation mouse embryos suggests specific developmental functions for different activins Development $1203621-3637$

*Findlay JK (1993) An update on the roles of inhibin, activin, and follistatin as local regulators of folliculogenesis Biology of Reproduction $\mathbf{4 8}$ $15-23$ 
*Galloway SM, McNatty KP, Cambridge LM et al. (2000) Mutations in an oocyte-derived growth factor gene (BMP15) cause increased ovulation rate and infertility in a dosage-sensitive manner Nature Genetics 25 279-283

*Guo Q, Kumar TR, Woodruff T, Hadsell LA, DeMayo FJ and Matzuk MM (1998) Overexpression of mouse follistatin causes reproductive defects in transgenic mice Molecular Endocrinology 12 96-106

Gurdon JB and Bourillot PY (2001) Morphogen gradient interpretation Nature 413 797-803

Hashimoto O, Nakamura T, Shoji H, Shimasaki S, Hayashi Y and Sugino H (1997) A novel role of follistatin, an activin-binding protein, in the inhibition of activin action in rat pituitary cells. Endocytotic degradation of activin and its acceleration by follistatin associated with cell-surface heparan sulfate Journal of Biological Chemistry 27213 835-13 842

*Hashimoto O, Kawasaki N, Tsuchida K, Shimasaki S, Hayakawa T and Sugino H (2000) Difference between follistatin isoforms in the inhibition of activin signalling: activin neutralizing activity of follistatin isoforms is dependent on their affinity for activin Cell Signal 12 565-571

Hillier SG (1991) Regulatory functions for inhibin and activin in human ovaries Journal of Endocrinology 131 171-175

Hillier SG and Miro F (1993) Inhibin, activin, and follistatin. Potential roles in ovarian physiology Annals of the New York Academy of Sciences 687 29-38

Hsueh AJ, Dahl KD, Vaughan J, Tucker E, Rivier J, Bardin CW and Vale W (1987) Heterodimers and homodimers of inhibin subunits have different paracrine action in the modulation of luteinizing hormone-stimulated androgen biosynthesis Proceedings National Academy of Sciences USA 84 5082-5086

lemura S, Yamamoto TS, Takagi C, Uchiyama H, Natsume T, Shimasaki S, Sugino H and Ueno $\mathbf{N}$ (1998) Direct binding of follistatin to a complex of bone-morphogenetic protein and its receptor inhibits ventral and epidermal cell fates in early Xenopus embryo Proceedings National Academy of Sciences USA 95 9337-9342

Iemura S, Yamamoto TS, Takagi C, Kobayashi H and Ueno N (1999) Isolation and characterization of bone morphogenetic protein-binding proteins from the early Xenopus embryo Journal of Biological Chemistry 27426 843-26 849

Inouye S, Guo Y, DePaolo L, Shimonaka M, Ling N and Shimasaki S (1991) Recombinant expression of human follistatin with 315 and 288 amino acids: chemical and biological comparison with native porcine follistatin Endocrinology 129 815-822

Kaufmann E, Paul H, Friedle H, Metz A, Scheucher M, Clement JH and Knochel W (1996) Antagonistic actions of activin A and BMP-2/4 control dorsal lip-specific activation of the early response gene XFD$1^{\prime}$ in Xenopus laevis embryos EMBO Journal 15 6739-6749

*Kingsley DM (1994) The TGF- $\beta$ superfamily: new members, new receptors, and new genetic tests of function in different organisms Genes and Development 8 133-146

Knight PG and Glister C (2001) Potential local regulatory functions of inhibins, activins and follistatin in the ovary Reproduction 121503 512

Kogawa K, Ogawa K, Hayashi Y, Nakamura T, Titani K and Sugino H (1991) Immunohistochemical localization of follistatin in rat tissues Endocrinologia Japonica 38 383-391

Lee SJ and McPherron AC (2001) Regulation of myostatin activity and muscle growth Proceedings National Academy of Sciences USA 98 9306-9311

Lee WS, Otsuka F, Moore RK and Shimasaki S (2001) Effect of bone morphogenetic protein-7 on folliculogenesis and ovulation in the rat Biology of Reproduction 65 994-999

Li R, Phillips DM and Mather JP (1995) Activin promotes ovarian follicle development in vitro. Endocrinology 136 849-856

Lindsell CE, Misra V and Murphy BD (1993) Regulation of follistatin messenger ribonucleic acid in porcine granulosa cells by epidermal growth factor and the protein kinase-C pathway Endocrinology 132 1630-1636

Lindsell CE, Misra V and Murphy BD (1994) Regulation of follistatin gene expression in the ovary and in primary cultures of porcine granulosa cells Journal of Reproduction and Fertility 100 591-597
Ling N, Ying SY, Ueno N, Esch F, Denoroy L and Guillemin R (1985) Isolation and partial characterization of a $\mathcal{M}_{\mathrm{r}} 32000$ protein with inhibin activity from porcine follicular fluid Proceedings National Academy of Sciences USA 82 7217-7221

Ling N, Ying SY, Ueno N, Shimasaki S, Esch F, Hotta M and Guillemin R (1986) Pituitary FSH is released by a heterodimer of the beta-subunits from the two forms of inhibin Nature 321 779-782

Liu X, Andoh K, Yokota H, Kobayashi J, Abe Y, Yamada K, Mizunuma H and Ibuki Y (1998) Effects of growth hormone, activin, and follistatin on the development of preantral follicle from immature female mice Endocrinology 139 2342-2347

Lyons K, Graycar JL, Lee A, Hashmi S, Lindquist PB, Chen EY, Hogan BL and Derynck R (1989) Vgr-1, a mammalian gene related to Xenopus Vg-1, is a member of the transforming growth factor beta gene superfamily Proceedings National Academy of Sciences USA 86 4554-4558

McGrath SA, Esquela AF and Lee SJ (1995) Oocyte-specific expression of growth/differentiation factor-9 Molecular Endocrinology 9 131-136

Macias-Silva M, Hoodless PA, Tang SJ, Buchwald M and Wrana JL (1998) Specific activation of Smad1 signaling pathways by the BMP7 type I receptor, ALK2 Journal of Biological Chemistry 27325 628-25 636

McPherson SJ, Mellor SL, Wang H, Evans LW, Groome NP and Risbridger GP (1999) Expression of activin A and follistatin core proteins by human prostate tumor cell lines Endocrinology 140 5303-5309

Massagué J (1998) TGF- $\beta$ signal transduction Annual Review of Biochemistry 67 753-791

*Massagué J and Wotton D (2000) Transcriptional control by the TGF$\beta /$ Smad signaling system EMBO Journal 19 1745-1754

Mather JP, Moore A and Li RH (1997) Activins, inhibins, and follistatins: further thoughts on a growing family of regulators Proceedings Society for Experimental Biology and Medicine 215 209-222

*Matzuk MM, Lu N, Vogel H, Sellheyer K, Roop DR and Bradley A (1995) Multiple defects and perinatal death in mice deficient in follistatin Nature 374 360-363

Mellor SL, Cranfield M, Ries R, Pedersen J, Cancilla B, de Kretser D, Groome NP, Mason AJ and Risbridger GP (2000) Localization of activin $\operatorname{beta}(\mathrm{A})-$, $\operatorname{beta}(\mathrm{B})-$, and beta(C)-subunits in human prostate and evidence for formation of new activin heterodimers of beta(C)-subunit Journal of Clinical Endocrinology and Metabolism 85 4851-4858

Michel U, Albiston A and Findlay JK (1990) Rat follistatin: gonadal and extragonadal expression and evidence for alternative splicing Biochemical and Biophysical Research Communications 173 401-407

Michel U, McMaster JW and Findlay JK (1992) Regulation of steadystate follistatin mRNA levels in rat granulosa cells in vitro. Journal of Molecular Endocrinology 9 147-156

Miro F and Hillier SG (1996) Modulation of granulosa cell deoxyribonucleic acid synthesis and differentiation by activin Endocrinology 137 464-468

Miro F, Smyth CD and Hillier SG (1991) Development-related effects of recombinant activin on steroid synthesis in rat granulosa cells Endocrinology 129 3388-3394

Miyanaga K, Erickson GF, DePaolo LV, Ling N and Shimasaki S (1993) Differential control of activin, inhibin and follistatin proteins in cultured rat granulosa cells Biochemical and Biophysical Research Communications 194 253-258

Mizunuma H, Liu X, Andoh K, Abe Y, Kobayashi J, Yamada K, Yokota H, Ibuki Y and Hasegawa $Y$ (1999) Activin from secondary follicles causes small preantral follicles to remain dormant at the resting stage Endocrinology 140 37-42

Nakamura T, Takio K, Eto Y, Shibai H, Titani K and Sugino H (1990) Activinbinding protein from rat ovary is follistatin Science $247836-838$

Nakatani A, Shimasaki S, Depaolo LV, Erickson GF and Ling N (1991) Cyclic changes in follistatin messenger ribonucleic acid and its protein in the rat ovary during the estrous cycle Endocrinology 129 603-611

Oda S, Nishimatsu S, Murakami K and Ueno N (1995) Molecular cloning and functional analysis of a new activin beta subunit: a dorsal mesoderminducing activity in Xenopus. Biochemical and Biophysical Research Communications 210 581-588

Ogawa K, Kurohmaru M, Sugino H and Hayashi Y (1994) Changes in the immunoreactivity of follistatin within preovulatory follicles after the 
primary gonadotrophin surge in rats Journal of Reproduction and Fertility 101 577-581

Onichtchouk D, Chen YG, Dosch R, Gawantka V, Delius H, Massague J and Niehrs C (1999) Silencing of TGF-beta signalling by the pseudoreceptor BAMBI Nature 401 480-485

Otsuka F, Yao Z, Lee T, Yamamoto S, Erickson GF and Shimasaki S (2000) Bone morphogenetic protein-15. Identification of target cells and biological functions Journal of Biological Chemistry 27539 52339528

*Otsuka F, Moore RK, lemura S, Ueno N and Shimasaki S (2001 a) Follistatin inhibits the function of the oocyte-derived factor BMP-15 Biochemical and Biophysical Research Communications 289 961-966

Otsuka F, Yamamoto S, Erickson GF and Shimasaki S (2001b) Bone morphogenetic protein-15 inhibits follicle-stimulating hormone (FSH) action by suppressing FSH receptor expression Journal of Biological Chemistry 27611 387-11 392

Otsuka F, Moore RK and Shimasaki S (2001c) Biological function and cellular mechanism of bone morphogenetic protein-6 in the ovary Journal of Biological Chemistry $27632889-32895$

Patel K, Makarenkova H and Jung HS (1999) The role of long range, local and direct signalling molecules during chick feather bud development involving the BMPs, follistatin and the Eph receptor tyrosine kinase EphA4 Mechanisms of Development 86 51-62

Phillips DJ and de Kretser DM (1998) Follistatin: a multifunctional regulatory protein Frontiers in Neuroendocrinology 19 287-322

Phillips DJ, McFarlane JR, Hearn MT and de Kretser DM (1997) Inhibin, activin and follistatin bind preferentially to the transformed species of alpha 2-macroglobulin Journal of Endocrinology 155 65-71

Phillips DJ, Jones KL, McGaw DJ, Groome NP, Smolich J, Parsson H and de Kretser DM (2000) Release of activin and follistatin during cardiovascular procedures is largely due to heparin administration Journal of Clinical Endocrinology and Metabolism 852411 2415

Roberts VJ, Barth S, el-Roeiy A and Yen SS (1993) Expression of inhibin/activin subunits and follistatin messenger ribonucleic acids and proteins in ovarian follicles and the corpus luteum during the human menstrual cycle Journal of Clinical Endocrinology and Metabolism 77 1402-1410

Robertson DM, Foulds LM, Leversha L, Morgan FJ, Hearn MT, Burger HG, Wettenhall RE and de Kretser DM (1985) Isolation of inhibin from bovine follicular fluid Biochemical and Biophysical Research Communications 126 220-226

Robertson DM, Klein R, de Vos FL, McLachlan RI, Wettenhall RE, Hearn MT, Burger HG and de Kretser DM (1987) The isolation of polypeptides with FSH suppressing activity from bovine follicular fluid which are structurally different to inhibin Biochemical and Biophysical Research Communications 149 744-749

Schlunegger MP and Grutter MG (1992) An unusual feature revealed by the crystal structure at $2.2 \AA$ resolution of human transforming growth factor-beta 2 Nature 358 430-434

Schmitt J, Hotten G, Jenkins NA, Gilbert DJ, Copeland NG, Pohl J and Schrewe H (1996) Structure, chromosomal localization, and expression analysis of the mouse inhibin/activin beta $C$ (Inhbc) gene Genomics 32 358-366

Schneyer AL, Hall HA, Lambert-Messerlian G, Wang QF, Sluss P and Crowley WF, Jr (1996) Follistatin-activin complexes in human serum and follicular fluid differ immunologically and biochemically Endocrinology 137 240-247

Shimasaki S, Koga M, Esch F, Mercado M, Cooksey K, Koba A and Ling N (1988a) Porcine follistatin gene structure supports two forms of mature follistatin produced by alternative splicing Biochemical and Biophysical Research Communications 152 717-723

*Shimasaki S, Koga M, Esch F, Cooksey K, Mercado M, Koba A, Ueno N, Ying SY, Ling N and Guillemin R (1988b) Primary structure of the human follistatin precursor and its genomic organization Proceedings National Academy of Sciences USA 85 4218-4222

Shimasaki S, Koga M, Buscaglia ML, Simmons DM, Bicsak TA and Ling N (1989) Follistatin gene expression in the ovary and extragonadal tissues Molecular Endocrinology 3 651-659
Shimasaki S, Zachow RJ, Li D, Kim H, lemura S, Ueno N, Sampath K, Chang RJ and Erickson GF (1999) A functional bone morphogenetic protein system in the ovary Proceedings National Academy of Sciences USA $967282-7287$

Shimonaka M, Inouye S, Shimasaki S and Ling N (1991) Follistatin binds to both activin and inhibin through the common subunit Endocrinology $1283313-3315$

Shintani Y, Dyson M, Drummond AE and Findlay JK (1997) Regulation of follistatin production by rat granulosa cells in vitro. Endocrinology 138 2544-2551

Shukovski L, Findlay JK and Robertson DM (1991) The effect of folliclestimulating hormone-suppressing protein or follistatin on luteinizing bovine granulosa cells in vitro and its antagonistic effect on the action of activin Endocrinology 129 3395-3402

Shukovski L, Dyson M and Findlay JK (1993) The effects of follistatin, activin and inhibin on steroidogenesis by bovine thecal cells Molecular and Cellular Endocrinology 97 19-27

Shukovski L, Keren-Tal I, Dantes A and Amsterdam A (1995) Regulation of follistatin messenger ribonucleic acid in steroidogenic rat granulosa cell lines Endocrinology 136 2889-2895

Sidis Y, Fujiwara T, Leykin L, Isaacson K, Toth T and Schneyer AL (1998) Characterization of inhibin/activin subunit, activin receptor, and follistatin messenger ribonucleic acid in human and mouse oocytes: evidence for activin's paracrine signaling from granulosa cells to oocytes Biology of Reproduction 59 807-812

Silva CC and Knight PG (1998) Modulatory actions of activin-A and follistatin on the developmental competence of in vitro matured bovine oocytes Biology of Reproduction $\mathbf{5 8}$ 558-565

Sugino K, Kurosawa N, Nakamura T, Takio K, Shimasaki S, Ling N, Titani K and Sugino H (1993) Molecular heterogeneity of follistatin, an activinbinding protein. Higher affinity of the carboxyl-terminal truncated forms for heparan sulfate proteoglycans on the ovarian granulosa cell Journal of Biological Chemistry 26815 579-15 587

Tano M, Minegishi T, Nakamura K, Nakamura M, Karino S, Miyamoto K and Ibuki Y (1995) Regulation of follistatin messenger ribonucleic acid in cultured rat granulosa cells Molecular and Cellular Endocrinology 109 167-174

Tisdall DJ, Hudson N, Smith P and McNatty KP (1994) Localization of ovine follistatin and alpha and beta A inhibin mRNA in the sheep ovary during the oestrous cycle Journal of Molecular Endocrinology 12 181-193

Tsuchiya M, Minegishi T, Kishi H, Tano M, Kameda T, Hirakawa T, Ibuki Y, Mizutani T and Miyamoto K (1999) Control of the expression of luteinizing hormone receptor by local factors in rat granulosa cells Archives of Biochemistry and Biophysics 367 185-192

Tuuri T and Ritvos O (1995) Regulation of the activin-binding protein follistatin cultured human luteinizing granulosa cells: characterization of the effects of follicle stimulating hormone, prostaglandin $\mathrm{E}_{2}$, and different growth factors Biology of Reproduction 53 1508-1516

Tuuri T, Eramaa M, Van Schaik RH and Ritvos O (1996) Differential regulation of inhibin/activin $\alpha$ - and $\beta A$-subunit and follistin mRNAs by cyclic AMP and phorbol ester in cultured human granulosa-luteal cells Molecular and Cellular Endocrinology 121 1-10

Ueno N, Ling N, Ying SY, Esch F, Shimasaki S and Guillemin R (1987) Isolation and partial characterization of follistatin: a single-chain $\mathrm{Mr}$ 35000 monomeric protein that inhibits the release of follicle-stimulating hormone Proceedings National Academy of Sciences USA 84 82828286

Vale W, Rivier J, Vaughan J, McClintock R, Corrigan A, Woo W, Karr D and Spiess J (1986) Purification and characterization of an FSH releasing protein from porcine ovarian follicular fluid Nature 321 776-779

Vejda S, Cranfield M, Peter B, Mellor SL, Groome N, Schulte-Hermann R and Rossmanith W (2002) Expression and dimerization of the rat activin subunits $\beta C$ and $\beta E$ : evidence for the formation of novel activin dimers Journal of Molecular Endocrinology 28 137-148

Vitt UA, Hayashi M, Klein C and Hsueh AJ (2000) Growth differentiation factor-9 stimulates proliferation but suppresses the follicle-stimulating hormone-induced differentiation of cultured granulosa cells from small antral and preovulatory rat follicles Biology of Reproduction 62370 377 
Wada M, Shintani Y, Kosaka M, Sano T, Hizawa K and Saito S (1996) Immunohistochemical localization of activin A and follistatin in human tissues Endocrine Journal 43 375-385

Webb R, Campbell BK, Garverick HA, Gong JG, Gutierrez CG and Armstrong DG (1999) Molecular mechanisms regulating follicular recruitment and selection Journal of Reproduction and Fertility Supplement 54 33-48

Wrathall JH and Knight PG (1995) Effects of inhibin-related peptides and oestradiol on androstenedione and progesterone secretion by bovine theca cells in vitro. Journal of Endocrinology 145 491-500

Xiao S, Robertson DM and Findlay JK (1992) Effects of activin and follicle-stimulating hormone (FSH)-suppressing protein/follistatin on $\mathrm{FSH}$ receptors and differentiation of cultured rat granulosa cells Endocrinology 131 1009-1016

Yamane Y, Tohno-oka R, Yamada S, Furuya S, Shiokawa K, Hirabayashi Y, Sugino H and Sugahara K (1998) Molecular characterization of
Xenopus embryo heparan sulfate. Differential structural requirements for the specific binding to basic fibroblast growth factor and follistatin Journal of Biological Chemistry 273 7375-7381

Yamashita H, ten Dijke P, Huylebroeck D, Sampath TK, Andries M, Smith JC, Heldin CH and Miyazono K (1995) Osteogenic protein-1 binds to activin type II receptors and induces certain activin-like effects Journal of Cell Biology 130 217-226

*Yan C, Wang P, DeMayo J et al. (2001) Synergistic roles of bone morphogenetic protein 15 and growth differentiation factor 9 in ovarian function Molecular Endocrinology 15 854-866

Yokota H, Yamada K, Liu X, Kobayashi J, Abe Y, Mizunuma H and Ibuki Y (1997) Paradoxical action of activin A on folliculogenesis in immature and adult mice Endocrinology 1384572 4576

Zimmerman CM and Padgett RW (2000) Transforming growth factor beta signaling mediators and modulators Gene 249 17-30 